http://dx.doi.org/10.7494/drill.2017.34.4.821

\author{
Albin Wojnar*, Czesław Rybicki*
}

\title{
AN ANALYSIS OF THE WORK CONDITIONS \\ IN THE BÓBRKA-ROGI FIELD \\ OVER THE 100 YEAR HISTORY OF ITS EXPLOITATION**
}

\section{INTRODUCTION}

The Bóbrka-Rogi oil field is located in the eastern part of the Bóbrka anticline, being one of the folds of the Silesian Unit in the Flysch Carpathians.

The Bóbrka-Rogi field was discovered in 1853 and oil extraction started in the second half of the $19^{\text {th }}$ century. Between the years 1853-1993, a total of 349 wells (and dozens of dug wells) were drilled in the area with the total production of 12,375,000 tons of oil, $190.5 \mathrm{mln} \mathrm{nm}$ of natural gas and 28,014,000 tons of reservoir water from the beginning of exploitation to the end of 2009 [3].

\section{GEOGRAPHICAL CHARACTERISTICS OF FIELD LOCATION}

Physio-geographically, the Bóbrka-Rogi field belongs to the Central Beskidian Piedmont. The surface is diversified and can be classified as submontane. It assumes the form of slopes and ridges running crosswise to the longitudinal axis of the field. Its elevation ranges between $370 \mathrm{~m}$ a.s.l. and $420 \mathrm{~m}$ a.s.l.

The field area, in the central part of the Jasiołka River, is urbanized. Most of it is overgrown with forest, with the Bóbrka Museum of the Oil and Gas Industry inside. A small part of the mining area is used for agricultural purposes, mainly as meadows. The main water course in the field site is the Jasiołka River, collecting water from a number of nameless little creeks.

On the surface, the field coincides with a network of asphalt roads. In the east, the Rzeszów-Barwinek road passes transversely to the field.

* AGH University of Science and Technology, Faculty of Drilling, Oil and Gas, Krakow, Poland

** The work was prepared within the framework of statutory research at the Faculty of Drilling, Oil and Gas AGH UST in 2017 
The Bóbrka-Rogi oil field is located in the Subcarpathian Voivodeship, Krosno County, in the following municipalities:

- Dukla Municipality: Równe, Wietrzno,

- Chorkówka Municipality: Bóbrka, Łęki Dukielskie,

- Miejsce Piastowe Municipality: Rogi.

\section{GEOLOGICAL SETTING}

The Bóbrka-Rogi oil field is located in the Silesian Unit in the central part of the Flysch Carpathian depression, in the eastern part of a smaller tectonic unit, i.e. the Bóbrka anticline [2].

The Silesian facies of the Flysch Carpathians cover a larger area; they extend from the eastern border to the Dunajec River at a distance of over $30 \mathrm{~km}$. From the south, the unit is covered with the Magura Nappe and reaches the edge of the Carpathians from the north. The Silesian Unit has a fully developed flysch of Lower Cretaceous to Oligocene time.

The Lower Cretaceous is represented by shales as well as Zechstein limestones and sandstones. Four beds were distinguished in this series, i.e. the Grodzisko, Wierzowiec, Lgota and Godula beds. The Upper Cretaceous strata are represented by the Istebna Beds. The Paleocene and Eocene beds are of great importance, e.g. Ciężkowice sandstones, which are the most abundant reservoir in the Carpathians. The Oligocene beds are represented by Menilite shales with Kliwa sandstones, and also the Krosno Beds.

The Bóbrka Fold extends from Szczawno in southeast, through Głębokie, Bóbrka, Kobylany, Świerchowa to Osobnica in the northwest. In its eastern section, between Szczawne and Klimkówka, there is a surface outcrop of lower sandstones from the Krosno Beds (200-300 $\mathrm{m}$ in width), with the local presence of Menilite shales in the area of Głębokie and Jaworowa Góra. The fold between Głębokie and Równe elevates, revealing the Menilite shales outcrop [2]. Moving westward from Bóbrka to Kobylany, the elevation becomes even more prominent, showing all levels of the Ciężkowice sandstones and the topmost Istebna shales. The elevation further increases on the Kobylany dislocation up to the transverse Łężyny dislocation, opening the Istebna series about 300-400 m wide. Starting from Łężyny, the fold lowers on numerous transverse dislocations to completely disappear in Załęże, whereas in the northwest direction it presents outcrops of the Krosno Beds, Menilite Beds, variegated shales in the area of Łazy Dębowieckie and Osobnica. The whole structure is about $70 \mathrm{~km}$ long. The Bóbrka Fold, anticlinal in character, leans mostly to the north, and in places is strongly overthrusted on the north side. One to several longitudinal dislocations appear over its length; some of them are visible on the surface, other are present in the core of the fold. Also numerous transverse dislocations appear in this area and, analogous to the longitudinal dislocations, only part of them can be seen on the surface. The following lithostratigraphic horizons are involved in the geological makeup of the fold:

- Istebna Beds, in the form sandstone-shale facies (Paleocene/Upper Cretaceous);

- Variegated shales with 4 horizons of Ciężkowice sandstones (Eocene, Paleocene);

- Menilite series with Kliwa-type sandstones (Oligocene);

- Krosno Beds - lower sandstones-shales and upper shales (Oligocene). 


\section{Stratigraphy}

The anticline in the Bóbrka-Rogi oil field is composed of the following stratigraphic parts:

- Krosno Beds (Oligocene),

- Menilite shales with hornstones (Oligocene),

- variegated shales I (Eocene),

- Ciężkowice sandstone I (Eocene),

- variegated shales II (Eocene),

- Ciężkowice sandstone II (Eocene),

- variegated shales III (Eocene),

- Ciężkowice sandstone III (Paleocene),

- variegated shales IV [in places divided into series a and b] (Paleocene),

- Ciężkowice sandstone IV [in places divided into series a and b] (Paleocene),

- Istebna shales [Czarnorzeka] (Paleocene),

- Istebna sandstones and shales [Czarnorzeka] (Upper Cretaceous).

All of these lithostratigraphic members have been found in the wells drilled in the Bóbrka-Rogi field. Reservoir rocks consisted of Ciężkowice sandstones (I-IV p-c - Eocene/ Paleocene), in the form of sandstone-shale complexes and a sandstone series in the Istebna Beds (Upper Cretaceous). The 'variegated Eocene' series consists of packages of thick-bedded sandstones interlaid with a series of greyish green and red shales. Sandstones are grey and light-grey, mostly medium- and coarse-grained, sometimes even conglomerates with a clayey binder. Fine-grained sandstones play a subordinate role in this system. Istebna sandstones are principally medium- and thick-bedded with a weak, mostly clayey binder, interlaid with packages of black and grey shales.

A detailed description of the geological makeup of the field has been included in geological documentation and appendices $[2,1]$.

\section{Tectonics}

The spatial makeup of the Bóbrka anticline in the Bóbrka-Rogi oil field section is similar to the remaining part of the anticline in the area where better recognized hydrocarbon accumulations appear. Numerous longitudinal dislocations are present in the whole field, from a single one in the eastern part (the Emilia Klarowiec Block) to four in the central part, and one more in the western part and six transverse dislocations, giving the field a block character. Deformations are mostly inclined, have various thrust amplitudes from dozens to hundreds of meters. Horizontal deformations of neighboring blocks were also observed on some transverse dislocations. Part of the deformations were observed on the surface, part of them occur only underground in the fold (they disappear towards the surface). They were found in the well profiles or were interpreted in the course of the analyses of drilling data obtained when solving reservoir problems.

Longitudinal dislocations divide the anticline in 'scales'. The northern one is the most elevated and mainly visible on the surface, with the outcrops of beds making up the fold. It was the object of the first geological-drilling surveys, and also the first extraction carried out in the shallowest oil horizons. To the south, the scales decline on the faults and assume deep 
underground structures but frequently their existence does not have any manifestation on the surface. As a result, they were discovered and opened for production with progressing drilling and prospecting technology.

The fold reaches the deepest areas in the eastern part of the field to rise on the successive transverse dislocations, and open older stratigraphic members on the surface. Over its entire length it leans towards the east.

Particular blocks of the field and horizons vary in their geological-reservoir conditions.

As the drilling works proceeded, the tectonic-reservoir blocks (separated with transverse dislocations) or their parts were given the names of the drilled wells, and later, after 1945, the names of nearby towns. Starting from the east we have:

- Emilia Klarowiec Block,

- August-Alma-Radium Block,

- Wietrznianka Block,

- Bóbrka Block (sometimes also called Nowa Bóbrka Block),

- Opal Block,

- Łęki Niepodległość Block.

One longitudinal dislocation observed on the Emilia Klarowiec Block divides it into north and south wings, and two transverse dislocations split it into its west, central and east parts. In the west element on the north side there is another longitudinal dislocation dividing this block into three 'scales' - a small accumulation was present only in the north 'scale' (no longer under extraction) and trace accumulation in the central one. The biggest and most abundant is the central element. It reaches deepest and the core of the fold manifests itself with Menilite outcrops on the surface. Extraction was conducted mainly on Ciężkowice sandstone I.

To the west we have the August-Alma-Radium Block, which is a large transverse fault (Jasiołka Fault) divided into eastern and western parts. Three longitudinal dislocations were found on this block and they split it into four 'scales'. In the west part, all 4 elements are productive, and in the east part, mainly the north scale remains productive. This block is slightly elevated and the core of the fold manifests itself with outcrops of variegated shales I. Accumulations are observed in all of the Ciężkowice sandstone horizons and Istebna Beds.

After World War II, the southernmost element of this block was given the name 'Wietrznianka' to commemorate the importance of the discovery and the individual character of the structure. The accumulations mainly concentrate in the Ciężkowice sandstone I, traces in Ciężkowice sandstone II, and no industrially significant accumulations of hydrocarbons in the deeper parts.

From the west this block limits a large transverse fault, the 'Uskok Wietrznianki'. Behind it there are Opal Block, Bóbrka Block and west part of Wietrznianka. Also here, three longitudinal dislocations divide the fold into four scales. This block is also slightly elevated in comparison to the previous one and the core of the fold manifests itself with outcrops of variegated shales II and Ciężkowice sandstone II on the surface. The oil horizons on the north scale and the neighboring one on the south were the first to be discovered and opened for extraction in the Bóbrka-Rogi field. The oil accumulation was found in Ciężkowice sandstone III, IV and Istebna sandstones. In the southern part we have the Bóbrka Block (Nowa Bóbrka), discovered in the post-war period, with oil accumulation mainly in the Ciężkowice sandstone III, and minor accumulations in the Ciężkowice sandstone IV. 
To the west, the fold elevates higher on the transverse dislocation, and the core of the fold manifests itself with outcrops of the Ciężkowice sandstone II in the east to Ciężkowice sandstone III in the west part. The east and west parts of this block bear the name of Opal Block and Łęki-Niepodległość Block, respectively. One longitudinal dislocation is observed on this block, and three were distinguished in the east, in the shallow parts of the rock mass. It should be stressed that the sides of the fold have not been well recognized, especially in the west part. In the east part of Opal Block the accumulation was noted in Ciężkowice sandstone III and IV and in Istebna sandstones. In the west part, the southern side of the fold is productive and extraction is conducted through the wells on the Istebna Beds. Two secondary folds appear on the north side, but no oil accumulation was confirmed there. These foldings are also visible on the Opal and Radium blocks.

The detailed geological makeup and reservoir tectonics are illustrated in the presented maps and geological cross-sections.

\section{DESCRIPTION OF THE STATE OF RECOGNITION OF THE FIELD}

The Bóbrka-Rogi oil field was discovered in 1853 with dug wells. This was the first discovered field in the Bóbrka anticline, where after the Potok fold it is the most abundant structure of the Silesian Unit. The earliest history of the mine was discussed in many works but poorly documented. According to the 'Plan of Bóbrka Mine' (exhibit in the Museum) in 1886 there were 63 hand-dug surface wells, timbered and manually deepened with the line and rod method to a maximum depth of $312 \mathrm{~m}$.

Over the years, wells were sunk at different depths and with varying degrees of intensity.

The geological documentation [2] gives a list of wells performed on this field at various time spans:

- 1862-1900 - minimum 154 wells and ten or so manually dug wells,

- 1901-1910 - 20 wells,

- 1911-1920 - 6 wells,

- 1921-1930 - 15 wells,

- 1931-1940 - 25 wells (August, Łęki)

- 1941-1950 - 69 wells (Bóbrka, Wietrznianka, Alma),

- 1951-1960 - 53 wells,

- 1961-1970 - 3 wells,

- 1971-1980 - 2 exploration wells - negative,

- 1991-1993 - 2 exploration wells - negative.

On the whole, 349 well were performed in the field area and its close vicinity [2-4], including $t 7$ with the rotary method and dozens of dug wells with a total footage of about 2,105,000 m.

\section{TYPE AND QUALITY OF THE PRODUCED USEFUL MINERALS}

Oil extracted from Bóbrka-Rogi field is paraffin-free and contains paraffin, light and medium, its density at a temperature of $20^{\circ} \mathrm{C}$ ranges from $0.820 \mathrm{~g} / \mathrm{cm}^{3}$ to $0.882 \mathrm{~g} / \mathrm{cm}^{3}$ with an average density of about $0.841 \mathrm{~g} / \mathrm{cm}^{3}$ (Bóbrka Mine - collective analyses) - ca. $0.850 \mathrm{~g} / \mathrm{cm}^{3}$ 
(Równe Mine - collective analyses). The viscosity of oil at $20^{\circ} \mathrm{C}$ ranges between $1.15^{\circ} \mathrm{E}$ and $3.00^{\circ} \mathrm{E}$, with the average viscosity of $1.34-1.53^{\circ} \mathrm{E}$. The properties of oils from particular elements of the field differ slightly: from light benzine oils to heavier oils and from paraffin-free to paraffin oils. Paraffin-free oils sporadically occur in Ciężkowice sandstone I, II and III in the shallowest horizons in the Opal and August blocks; in the remaining part of the field, oils are qualified as paraffin oils.

\section{CHARACTERISTICS OF EXPLOITATION \\ IN THE BÓBRKA-ROGI FIELD \\ USING THE EXAMPLE OF CIĘŻKOWICE SANDSTONE III}

The following blocks were distinguished on the Bóbrka-Rogi oil field after documentation in $[1,2]$ :

- August block deposited in Ciężkowice sandstone III and IV,

- Alma block deposited in Ciężkowice sandstone III and IV,

- Radium block deposited in Ciężkowice sandstone III,

- Opal block deposited in Ciężkowice sandstone III and IV,

- Nowa Bóbrka deposited in Ciężkowice sandstone III

Extraction in particular blocks followed this schedule.

\section{Blok August}

The course of oil, natural gas and water extraction in August Block in 1945-2015 is presented in Figure 1.

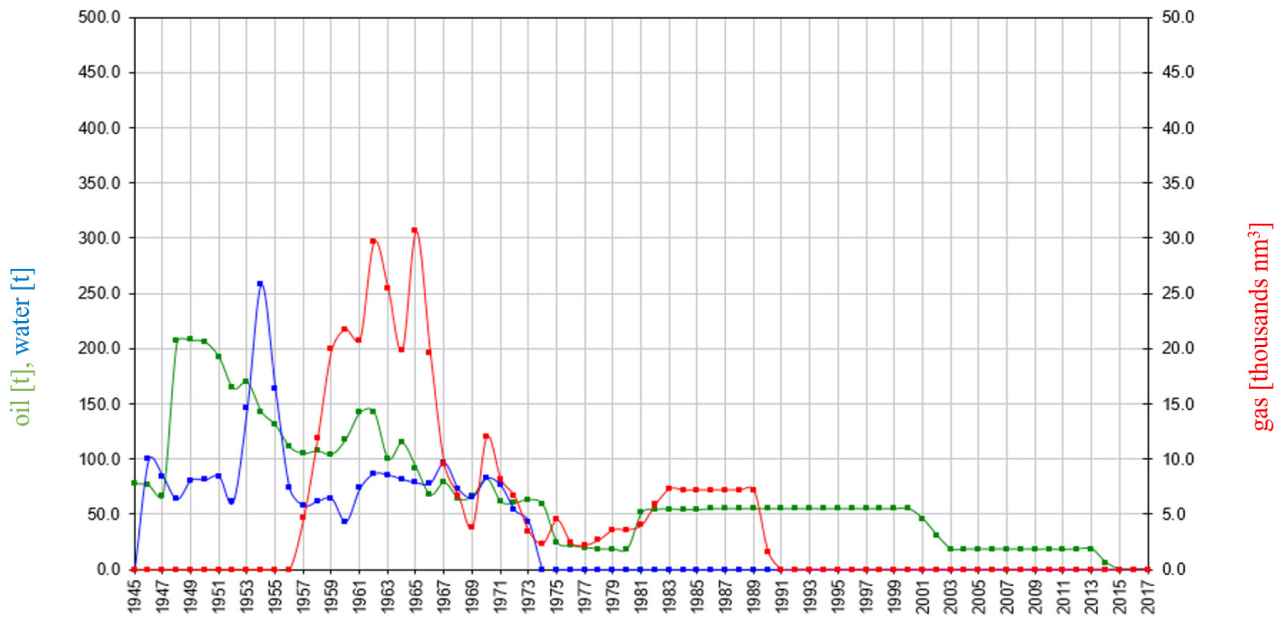

Fig. 1. Production of crude oil, natural gas and water in the August block between 1945-2015

(Ciężkowice sandstone III)

Source: [2] 
The analysis of the plot reveals that in the years 1945-1956 no gas production from the exploited wells was reported (zero on the plot). It can be concluded that oil extraction in 1945-1950 increased from $70 \mathrm{t}$ /year to $210 \mathrm{t} /$ year. At that time, water production was maintained at the level of $70 \mathrm{t} / \mathrm{year}$. Starting from the year 1950 we can observe a gradual decrease of oil production from 210 t/year to 100 t/year in 1999 at a simultaneous rapid increase of water production to $260 \mathrm{t} /$ year in 1954, after which the production of water drops to the level of $60 \mathrm{t}$ /year. The documented gas extraction shows that since 1956 the gas production had rapidly increased to $31,000 \mathrm{~nm}^{3} /$ year before falling in $1965-1969$ to about $5000 \mathrm{~nm}^{3} /$ year. The production of water accompanying oil and gas extraction was maintained at a constant level of $70 \mathrm{t} /$ year. Oil extraction was observed to gradually decrease to about $25 \mathrm{t} / \mathrm{year}$ in 1975 and was maintained at a constant level for the next five years. A slight change in gas production was noted and water production had ceased by 1970. In 1981, an almost twofold increase in oil production, to about $50 \mathrm{t} / \mathrm{year}$, was observed. This tendency was maintained until the year 2000. In 2002-2003 oil extraction dropped from $50 \mathrm{t} /$ year to $20 \mathrm{t}$ /year, a value which was maintained at a constant level until 2013. In 2015, oil extraction in the August Block was terminated. The analyzed course of oil production shows the character of field operation. By 1975, oil flow to the wells was aided by a combination of gas and the inflowing water. After 1975, the produced oil was almost devoid of gas or the quantities were very small. The major force responsible for oil inflow was gravitational.

\section{The Alma and Radium blocks}

A plot representing the production of oil, natural gas and water in Alma and Radium blocks is illustrated in Figure 2.

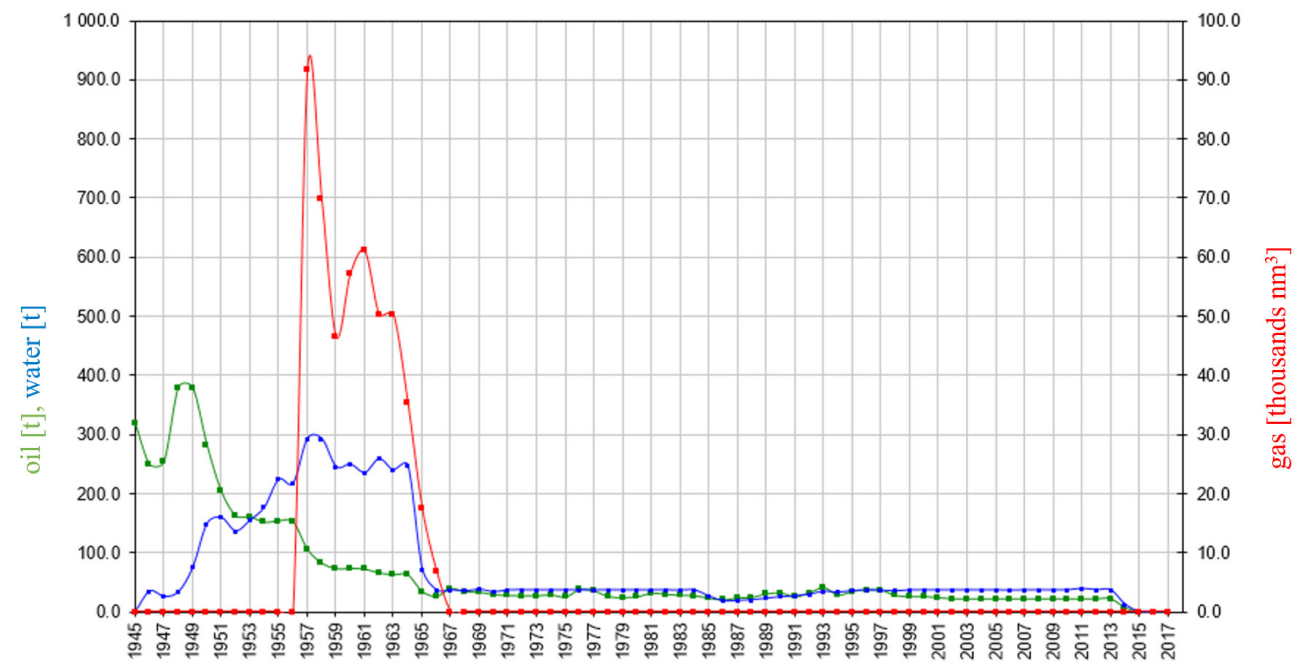

Fig. 2. Production of crude oil, natural gas and water in Alma and Radium blocks

(Ciężkowice sandstone III)

Source: [2] 
Attention should be paid to the fact that, analogous to the August Block, the reporting of gas production began in 1956. Gas extraction was observed to significantly increase to $92,000 \mathrm{~nm}^{3}$ and then dropped to extremely low values in 1967. Since that time gas has not participated in the general production. In the years 1945-1960 production decreased slightly, with periods of constant extraction in 1952-1956 and 1959-1962. Since 1967, annual oil and water extraction remained at an almost constant level of 3-4 t each. Analogous to the analysis of recorded production in the August Block, the initial period of oil extraction was determined by gaseous energy, either dissolved or liberated from oil or free gas in the caprock, and also by means of the inflowing water.

Since 1967, the typical gravity inflow of oil and water has been observed. As already mentioned, the participation of gas in the extracted reservoir fluid was of a trace character.

\section{The Opal Block}

Figure 3 illustrates the production of oil, gas and water in the Opal Block.



Fig. 3. Production of crude oil, natural gas and water in the Opal block (Ciężkowice sandstone III)

Source: [2]

The analysis of the plot reveals that the participation of gas in production is negligible. The oil extraction had a declining tendency from $300 \mathrm{t} /$ year in 1945 to $6 \mathrm{t} /$ year in 2013.

Oil extraction in the analyzed period is accompanied by high water production, which is evidence of a rapid water flux towards the wells or the improper opening of fluid flow zones. Water extraction in the analyzed period changed from $1500 \mathrm{t} /$ year in 1955 to $300 \mathrm{t} /$ year in 2013.

\section{The Nowa Bóbrka Block}

The oil, gas and water extraction in the Nowa Bóbrka Block is presented in Figure 4.

The analysis of the figure reveals that oil, gas and water extraction plots have a similar course. In the years 19511953 to 1959, 1961, a rapid increase of oil production to 9000 t/year 
and gas to $2.4 \mathrm{mln} \mathrm{nm}^{3} /$ year was observed. After a short period of maximum output in 1977 , the production of both fluids drops down to $1500 \mathrm{t}$ oil/year and $260,000 \mathrm{~nm}^{3} \mathrm{gas} /$ year. These values were maintained at an almost constant level to the year 1989, then the gas yield rapidly dropped to negligible values and oil production fell slightly to about $400 \mathrm{t}$ /year. Oil extraction is accompanied by water production at almost the same level. This type of extraction confirms the characteristic production system for the Bóbrka-Rogi field, i.e. gravity system.

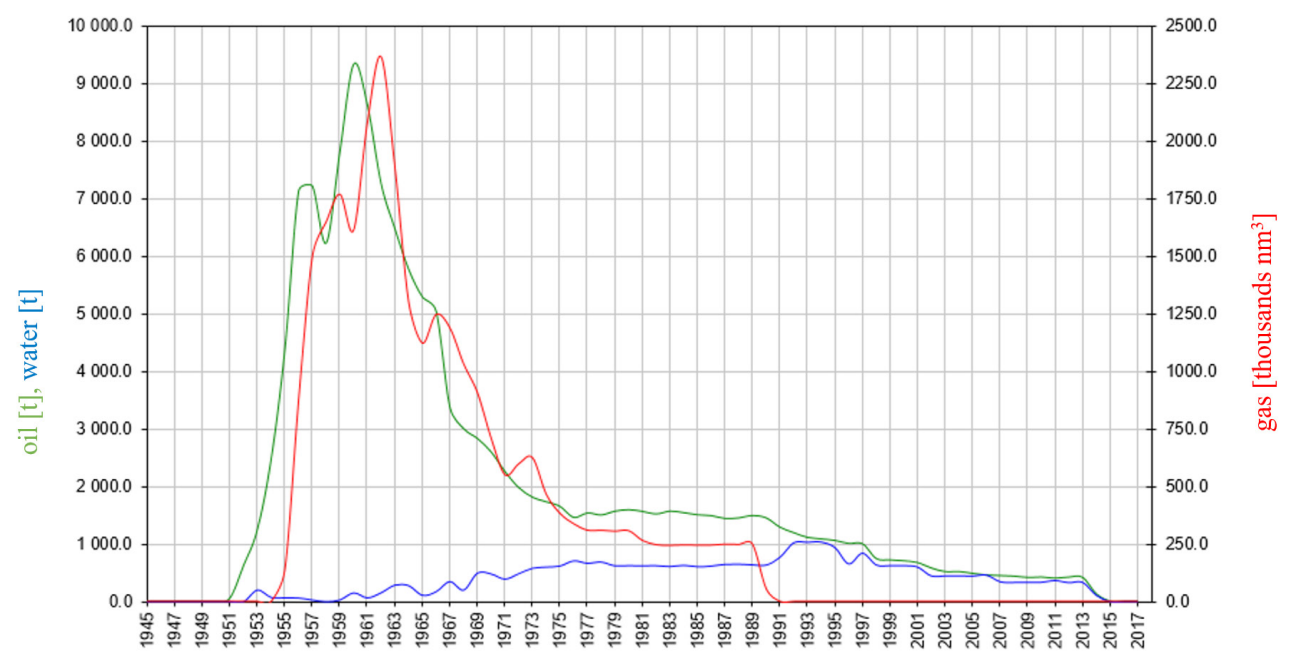

Fig. 4. Production of crude oil, natural gas and water in the Nowa Bóbrka block

(Ciężkowice sandstone III)

Source: [2]

\section{CONCLUDING REMARKS}

The following conclusions can be drawn from the analysis of production in the BóbrkaRogi field and the major productive horizon, i.e. Ciężkowice sandstone III:

1. In the initial period of production, the Bóbrka-Rogi field had a high yield of gas which had not been practically reported.

2. The high gas production in the initial period only partly brought about energy for oil extraction,

3. This type of production in the Bóbrka-Rogi field (which was improper according to the authors) quickly led to gas depletion in the oil, and thus an increase in its viscosity, causing considerable losses and hindering the recuperation of oil from the reservoir rock.

4. After the initial rapid degassing of the oil, the only mechanism facilitating oil inflow to the wells was gravitational. Its efficiency depended on the petrophysical properties of reservoir rocks and the spatial placement of the exploited horizons. 


\section{REFERENCES}

[1] Biuletyn Instytutu Geologicznego, nr 215, t. XII. Wydawnictwa Geologiczne, Warszawa 1968, pp. 79-138.

[2] Dokumentacja geologiczna złoża ropy naftowej Bóbrka-Rogi. Sanok 2010.

[3] Karnkowski P.: Złoża gazu ziemnego i ropy naftowej w Polsce, Karpaty i Zapadlisko Przedkarpackie, t. 2. Kraków 1993.

[4] Wdowiarz S.: Ropa naftowa i gaz ziemny na tle geologii Karpat. Warszawa 1960. 